\title{
IMPLEMENTASI KEBIJAKAN DISKRESI PADA SISTEM PELAYANAN PUBLIK DI KOTA TEGAL
}

\author{
Ikmal Jaya \\ Walikota Tegal \\ Ikmal_jaya00@yahoo.com
}

\begin{abstract}
Bureaucratic discretion in local government as one of the efforts the effectiveness of public services in Tegal city publication in urgent circumstances is a condition that arises suddenly public interest that must be resolved quickly, which to resolve the issue, the legislation has not been set. The approach used in this study is a socio-juridical approach, the method or procedure used to solve research problems by examining secondary data such as material laws or regulations applicable law followed by conducting research on primary data in the field. The results obtained that 1) Discretion Policy Implementation bureaucracy in local government as one of the efforts the effectiveness of public services in Tegal publication in urgent circumstances is a condition that arises suddenly public interest that must be resolved quickly, which to resolve the issue the legislation has not been set or just set in general and the situation should not be created due to error or action by the Board of Administration officials who perform discretionary, 2) Constraints in the discretion of the bureaucracy in local government as one of the efforts of service effectiveness public in Tegal is insufficient fee due to excessive demand of bureaucratic discretion program.
\end{abstract}

Keywords: Bureaucratic Discretion, Public Service

\begin{abstract}
Abstrak
Diskresi birokrasi dalam pemerintahan daerah sebagai salah satu upaya efektivitas pelayanan publik di Kota Tegal diterbitkannya dalam keadaan mendesak yaitu suatu keadaan yang muncul secara tiba-tiba menyangkut kepentingan umum yang harus diselesaikan dengan cepat, dimana untuk menyelesaikan persoalan tersebut, peraturan perundang-undangan belum mengaturnya. Metode pendekatan yang digunakan dalam penelitian ini adalah pendekatan yuridis sosiologis, yaitu cara atau prosedur yang digunakan untuk memecahkan masalah penelitian dengan meneliti data sekunder yang berupa bahan-bahan hukum atau peraturan-peraturan hukum yang berlaku kemudian dilanjutkan dengan mengadakan penelitian terhadap data primer di lapangan. Hasil penelitian yang diperoleh bahwa 1) Implementasi Kebijakan Diskresi birokrasi dalam pemerintahan daerah sebagai salah satu upaya efektivitas pelayanan publik di Kota Tegal diterbitkannya dalam keadaan mendesak yaitu suatu keadaan yang muncul secara tibatiba menyangkut kepentingan umum yang harus diselesaikan dengan cepat, dimana untuk menyelesaikan persoalan tersebut, peraturan perundang-undangan belum mengaturnya atau hanya mengatur secara umum dan keadaan tersebut tidak boleh tercipta karena kesalahan tindakan oleh Badan atau Pejabat Administrasi Pemerintahan yang melakukan diskresi, 2) Kendala-kendala di dalam diskresi birokrasi dalam pemerintahan daerah sebagai salah satu upaya efektivitas pelayanan publik di Kota Tegal adalah biaya yang tidak mencukupi akibat permintaan yang berlebihan dari program diskresi birokrasi.
\end{abstract}

Kata kunci: Diskresi Birokrasi, Pelayanan Publik. 


\section{A. Pendahuluan}

Peralihan kekuasaan yang semula didominasi oleh pemerintah pusat kini kekuasaan berada ditangan penyelenggara pemerintahan daerah. Suatu bukti komitmen untuk meningkatkan kesejahteraan rakyat masih sebatas wacana, dapat dilihat dari kebijakan Anggaran Pendapatan dan Belanja Daerah (APBD) yang lebih mengutamakan belanja rutin daripada untuk pembangunan yang dapat dinikmati langsung oleh masyarakat. Bukti bahwa komitmen pemerintah dalam mempriotitaskan pelayanan dibidang pendidikan dan kesehatan pun juga belum nampak secara tegas. Banyaknya penyimpangan yang dilakukan para elit politik, baik yang berada dalam domain legislatif maupun eksekutif, semakin menurunkan citra pemerintahan serta lembaga legislatif. Demikian pula kepercayaan masyarakat terhadap birokrasi pemerintah makin rendah ${ }^{1}$.

Rendahnya kualitas pelayanan publik ini antara lain disebabkan masih rendahnya profesionalisme birokrasi sehingga birokrasi tidak mampu memanfaatkan ruang diskresi yang seharusnya dapat digunakan dalam rangka meningkatan responsivitas terhadap tuntutan masyarakat. Diskresi birokrasi pemerintah daerah sebagai katup pengaman adanya kesenjangan kebijakan (terutama yang ditetapkan Pusat) dengan kebutuhan riil masyarakat di daerah yang lebih dinamis, ternyata belum digunakan sebagaimana mestinya. Masih banyak ditemukan adanya kebijakan dan peraturan yang dilaksanakan di daerah yang ternyata kurang sesuai dan tidak menjawab kebutuhan masyarakat secara riil. Faktor penyebab ketidak sesuaian itu bukan saja karena kebijakan lebih banyak ditentukan oleh pemerintah pusat, melainkan juga karena pejabat penyelenggara pemerintahan daerah belum dapat sepenuhnya melaksanakan visi dan komitmen untuk kesejahteraan rakyat ${ }^{2}$.

Besarnya kekuasaan birokrasi ternyata tidak identik dengan tingginya pelaksanaan diskresi birokrasi. Untuk pelayanan publik kadangkala

1 Teguh Yuwono, Otonomi Daerah Berjalan di Tempat, Harian Umum Suara Merdeka, 28 Desember 2009, hlm. 21

2 Warsito dan Teguh Yuwono, 2003, Otonomi Daerah: Capacity Building dan Penguatan Demokrasi Lokal, Puskodak-Undip,Semarang, hlm.81. diperlukan kewenangan diskresi yang tidak diatur dalam undang-undang atau kebijakan tertentu, bahkan dapat bertentangan dengan undang-undang yang sudah ada. Hal itulah yang biasa disebut sebagai hak prerogatif eksekutif. Kewenangan diskresi diperlukan karena tidak ada undang-undang yang mampu mengantisipasi setiap kejadian dan konsekwensi-konsekwensi yang tidak diinginkan. Oleh karenanya eksekutif perlu mendapat ruang dimana mereka dapat mengambil keputusan atau melakukan tindakan diantara alternatif-alternatif yang bisa dilakukannya.

Dalam menegaskan konsep bahwa birokrasi dengan diskresi yang dimiliki tersebut secara signifikan mendorong peningkatan profesionalisme dan kualitas pelayanan public. Konsep reinventing government yang tengah banyak diadopsi di Indonesia, yang menekankan pentingnya otonomi dan diskresi ternyata tidak serta merta menghasilkan perubahan yang signifikan dalam hal peningkatan kualitas pelayanan publik. Hal ini tidak lain karena upaya reinventing government melalui otonomi masih memerlukan serangkaian prasyarat pendukung yang perlu terlebih dahulu dikembangkan melalui program-program pembangunan kapasitas (capacity building) yang tentunya memerlukan waktu dan proses yang relatif panjang.

Menurut Kamus Hukum, diskresi berarti kebebasan mengambil keputusan dalam setiap situasi yang dihadapi menurut pendapatnya sendiri. ${ }^{3}$ Sedangkan didalam Rancangan Undang-Undang Administrasi Pemerintahan Draft bulan Juli 2008 di dalam Pasal 6 mengartikan diskresi sebagai wewenang badan atau pejabat pemerintahan dan atau badan hukum lainnya yang memungkinkan untuk melakukan pilihan dalam mengambil tindakan hukum dan atau tindakan faktual dalam administrasi pemerintahan. Ada beberapa pakar hukum yang memberikan definisi diskresi diantaranya S. Prajudi Atmosudirjo yang mendefinisikan diskresi, discretion (Inggris), discretionair (Perancis), freies ermessen (Jerman) sebagai kebebasan bertindak atau mengambil keputusan dari para pejabat administrasi negara yang berwenang dan berwajib menurut pendapat sendiri. Selanjutnya dijelaskannya bahwa diskresi

3 JCT Simorangkir dkk, 2008, Kamus Hukum, Sinar Grafika, Jakarta, hlm.38. 
diperlukan sebagai pelengkap dari asas legalitas, yaitu asas hukum yang menyatakan bahwa setiap tindak atau perbuatan administrasi negara harus berdasarkan ketentuan Undang-Undang. ${ }^{4}$

Akan tetapi tidak mungkin bagi undangundang untuk mengatur segala macam kasus posisi dalam praktek kehidupan sehari-hari. Oleh sebab itu perlu adanya kebebasan atau diskresi dari administrasi negara yang terdiri atas diskresi bebas dan diskresi terikat.

Pada diskresi bebas, Undang-undang hanya menetapkan batas-batas dan administrasi negara bebas mengambil keputusan apa saja asalkan tidak melampaui/melanggar batas-batas tersebut, sedangkan pada diskresi terikat, Undang-undang menetapkan beberapa alternatif keputusan dan administrasi negara bebas memilih salah satu alternatif keputusan yang disediakan oleh Undang-undang.

Indroharto menyebut wewenang diskresi sebagai wewenang fakultatif, yaitu wewenang yang tidak mewajibkan badan atau pejabat tata usaha negara dalam menerapkan wewenangnya, tetapi dapat memberikan pilihan sekalipun hanya dalam hal tertentu sebagaimana ditentukan dalam peraturan dasarnya.

Di masa otonomi di mana peran pemerintah daerah begitu "powerfull" dengan besarnya kewenangan otonom yang dimilikinya. Alih-alih dengan kewenangan yang besar itu digunakan untuk memperbaiki kinerja pemerintah dan pelayanan publik, justru dalam prakteknya seringkali pemerintah daerah mengusung praktikpraktik KKN. Kasus di daerah seperti maraknya proyek titipan, meyimpangan pengelolaan keuangan daerah dan masih banyak kasus lain dalam penyelenggaran pemerintahan daerah membuktikan bahwa telah terjadi penyalahgunaan kekuasaan oleh "penguasa" daerah. Dengan Otonomi Daerah diharapkan dapat mendekatkan pemerintah dengan rakyat sehingga kepentingan rakyat daerah semakin mudah terakomodir yang pada gilirannya mempercepat peningkataan kesejahteraan rakyat.

Paradigma penyelenggaraan pemerintahan daerah dengan structural-efficiency model telah harus digeser dengan paradigma local-democracy

4 S. Prajudi Atmosudirjo, 1994, Hukum Administrasi Negara, Ghalia Indonesia, Jakarta, hlm.82. model. ${ }^{5}$ Pemerintah daerah harus mengakomodir berbagai perbedaan aspirasi melalui forumforum stakeholders untuk dapat merumuskan kepentingan umum dan menentukan prioritas dalam proses kebijakan publik di tingkat daerah maupun pusat. Namun dalam perjalanannya, pelaksanaan demokrasi rakyat belum berjalan sebagaimana seharusnya. Suara dan aspirasi rakyat masih sekedar 'komoditas' politik yang dimanfaatkan oleh sebagian partai politik dan politisi untuk mencapai kekuasaan. Bahkan lembaga DPRD yang merupakan representasi rakyat seringkali bersikap tidak menjadi wakil rakyat, melainkan hanya mewakili partai politiknya atau bahkan dirinya sendiri.

SF Marbun mengatakan bahwa dengan diberikannya kebebasan bertindak (freies ermessen) kepada administrasi negara dalam melaksanakan tugasnya mewujudkan welfare state atau social rechtstaat di Belanda sempat menimbulkan kekhawatiran bahwa akibat dari freies ermessen akan menimbulkan kerugian bagi warga masyarakat ${ }^{6}$.

Fakta yang tertuang secara jelas di atas menjadi dasar disusunnya beberapa persoalan yang akan dibahas secara mendalam pada jurnal ini yaitu :

1. Bagaimanakah Implementasi Kebijakan diskresi birokrasi dalam pemerintahan daerah sebagai salah satu upaya efektivitas pelayanan publik di Kota Tegal?

2. Apakah kendala-kendala dalam mengimplementasikan kebijakan diskresi birokrasi dalam pemerintahan daerah sebagai salah satu upaya efektivitas pelayanan publik di Kota Tegal?

\section{B. METODE PENELITIAN}

Metode pendekatan yang digunakan dalam penelitian ini adalah pendekatan yuridis sosiologis atau socio legal research, yaitu cara atau prosedur yang digunakan untuk memecahkan masalah

5 Samodra Wibawa, 2009, Administrasi Negara: IsuIsu Kontemporer, Graha IImu, Yogyakarta, hlm 56.

6 SF Marbun, Menggali dan Menemukan Asas-asas Umum Pemerintahan yang Baik Di Indonesia, dalam SF Marbun dkk, Dimensi-Dimensi Pemikiran Hukum Administrasi Negara, 2001, UII Press, Yogyakarta, hlm 205. 
penelitian dengan meneliti data sekunder yang berupa bahan-bahan hukum atau peraturanperaturan hukum yang berlaku kemudian dilanjutkan dengan mengadakan penelitian terhadap data primer di lapangan. Penelitian ini dimaksudkan dengan penelitian untuk menemukan in concreto, ${ }^{7}$ yakni diskresi birokrasi dalam pemerintahan daerah sebagai salah satu upaya efektivitas pelayanan publik.

\section{HASIL PENELITIAN DAN PEMBAHASAN}

1. Implementasi kebijakan Diskresi Birokrasi Pemerintahan Daerah sebagai Salah Satu Upaya Efektivitas Pelayanan Publik di Kota Tegal

Di dalam menjalankan pemerintahan, Pemerintah telah dilengkapi dengan beberapa kewenangan yang bersifat atributif maupun yang bersifat delegatif. Dengan adanya perkembangan sosial di masyarakat, seringkali terdapat keadaan mendesak yang menyebabkan Badan administrasi pemerintahan tidak dapat menggunakan kewenangannya, khususnya kewenangan yang bersifat terikat (gebonden bevoegheid) dalam melakukan tindakan hukum dan tindakan faktual secara normal.

Sebagai negara yang bertujuan memajukan kesejahteraan umum, melekatnya fungsi dalam memajukan kesejahteraan umum dalam welfare state (negara kesejahteraan) menimbulkan beberapa konsekuensi terhadap penyelenggaraan pemerintahan yaitu pemerintah harus berperan aktif dalam mencampuri bidang kehidupan sosial ekonomi masyarakat. Untuk itu pemerintah dilimpahkan bestuurszorg atau Public Service.

Agar pelayanan publik dapat dilaksanakan dan mencapai hasil maksimal, kepada administrasi negara diberikan suatu kemerdekaan tertentu untuk bertindak atas inisiatif sendiri menyelesaikan berbagai permasalahan

7 Ronny Hanintijo Soemitro, 1990, Metode Penelitian Hukum dan Jurimetri, Ghalia Indonesia, Jakarta, hIm.12. pelik yang membutuhkan penanganan secara cepat, sementara terhadap permasalahan itu tidak ada, atau masih belum dibentuk suatu dasar hukum penyelesaiannya oleh lembaga legislatif yang kemudian dalam hukum administrasi negara diberikan kewenangan bebas berupa diskresi.

Berdasarkan hasil penelitian yang dilakukan oleh penulis, dalam mendeskripsikan beberapa kebijakan diskresi birokrasi oleh pemerintah Kota Tegal salah satunya adalah kebijakan Jaminan Kesehatan Masyarakat Semesta.

Jaminan Kesehatan Masyarakat Semesta adalah suatu kebijakan dari pemerintah Kota Tegal untuk menyelenggarakan pelayanan kesehatan yang bermutu dan berkeadilan dikhususkan dalam pembiayaan bagi masyarakat yang belum ditanggung oleh jaminan kesehatan lainnya. Implementasi kebijakan diskresi ini apabila ditelaah dan dikaji dari berbagai sudut pandang melalui beberapa analisis dapat ditinjau dari beberapa aspek sebagai berikut :

a. Aspek Yuridis Formal

Tinjauan yuridis formal atas pembiayaan kesehatan tidak dapat dilepaskan dari Undang-undang Dasar 1945 pasal $26 \mathrm{H}$ yang menyatakan bahwa kesehatan adalah hak dasar bagi setiap warga negara. Selanjutnya dalam Undang-undang Nomor 36 Tahun 2009 tentang Kesehatan secara rinci dalam Pasal 4 sampai dengan Pasal 8 dijelaskan bahwa mengenai hak-hak masyarakat akan keehatan yang meliputi hak mendapatkan akses sumber daya kesehatan, hak untuk mendapatkan layanan kesehatan yang terjangkau dan bermutu, hak mendapatkan informasi dan edukasi yang benar dan bertanggungjawab serta hak mendapatkan data kesehatan dirinya dan pengobatan yang telah maupun yang akan diterimanya dari tenaga kesehatan. 
b. Aspek Sosiologis

Aspek sosiologis menjadi pertimbangan penting diperlukan dalam upaya peningkatan pelayanan kesehatan sekaligus dalam memutuskan kebijakan pembiayaan melalui Jamkesta di Kota Tegal Tahun 2013. Aspek ini lebih mencermati pada budaya atau perilaku pencarian pengobatan pada kultur masyarakat perkotaan demikian pula sosio kulturnya

c. Aspek Sumber Daya Kesehatan Aspek sumber daya kesehatan lebih dikaji sebagai suatukekuatan yang dapat dimanfaatkan untuk menunjang pelaksanaan program Jamkesta. Dari sisi fasilitas, jumlah sarana prasarana kesehatan maupun penunjang sarana kesehatan adalah sangat memadai untuk memberikan pelayanan terhadap 249.741 jiwa. Jumlah Puskesmas yang ada sebanyak 8 Puskesmas dengan 1 Puskesmas Rawat Inap, 7 Puskesmas mampu persalinan, 24 Puskesmas Pembantu, 1 rumah Sakit Umum tipe $B$, dengan jumlah bed di RSU Kardinah sebanyak 287 , ada 2 rumah sakit umum milik swasta, 1 Balai Pengobatan Paru-paru serta sarana kesehatan swasta lainnya yang tersebar di seluruh penjuru Kota Tegal.

d. Aspek Upaya Kesehatan Bersumberdaya masyarakat (UKBM)

Sumber daya kesehatan berbasis masyarakat juga menjadi satu kekuatanyang dapatdimanfaatkan untuk pelaksanaan Jamkesta. Peranan unit-unit UKBM seperti Kelurahan Siaga, Posyandu dan lain sebagainya dapat dijadikan jaringan informasi melalui para kadernya e. Aspek Pembiayaan

Ketepatan perhitungan biaya yang akan ditanggung untuk masyarakat sangat penting. Perhitungan dapat didasari pada jumlah sasaran, prediksi utilisasi, kajian epidemologi dan besaran kasus berkunjung ke Puskesmas dan rumah Sakit dan biaya pengobatan sesuai standar yang ada yang digunakan oleh Puskesmas dan Rumah Sakit serta pertimbangan pemanfaatan anggaran ddari Program Jamkesta tahun sebelumnya. Perhitungan yang tepat akan menekan potensial problem.

f. Infrastruktur dan Sistem Kendali Infrastruktur di sini adalah satu organisasi yang akan mengelola pembiayaan maupun mengendalikan sistem pelayanan kesehatannya. Dalam SOTK terdapat SKPD Dinas Kesehatan sebagai pelaksana regulasi Jamkesta dan BLUD RSUD Kardinah sebagai sentra pelayanan kesehatannya

Dalam perkembangan selanjutnya pemerintah Kota Tegal merencanakan satu kebijakan khusus untuk meningkatkan akses pelayanan kesehatan masyarakat melalui pembiayaan kesehatan. Pembiayaan kesehatan ini bersifat total coverage atau semesta. Kebijakan ini diterapkan kepada masyarakat Kota Tegal dengan batasan masyarakat yang belum dijamin oleh jaminan kesehatan yang ada seperti askes, jamkesmas dan asuransi lainnya

Kebijakan yang bersifat semesta ini diterapkan pada tahun 2013 selaras dengan Undang-undang Nomor 40 Tahun 2004 tentang Sistem Jaminan Sosial Nasional namun penerapannya mendahului Undang-undang tersebut. Dalam Undang-undang tersebut pelaksanaan sistem jaminan sosial nasional akan dimulai pada tahun 
2014, namun demikian pemerintah Kota Tegal memandang bahwa upaya kesemestaan dalam pembiayaan adalah upaya dalam peningkatan pelayanan publik dalam pelayanan kesehatan yang secara empirik masyarakat sangat merasakan manfaatnya. Kebijakan ini juga sekaligus sebagai wujud memenuhi hak dasar masyarakat akan kesehatannya yang bermuara pada kesejahteraan masyarakat.

Namun penerapan kebijakan diskresi dalam bidang jaminan kesehatan masyarakat semesta ini di Kota Tegal tetap mengacu pada koridor amanat Undang-undang Nomor 40 Tahun 2004 tentang Sistem Jaminan Sosial Nasional khususnya pada tujuan yang ingin dicapai, dilakukan untuk kepentingan umum dan tidak melanggar azas-azas umum pemerintahan yang baik serta tidak bertentangan dengan peraturan perundang-undangan lainnya yang mengatur mengenai pembiayaan kesehatan seperti Undang-undang Nomor 24 Tahun 2011 tentang Badan Penyelenggara Jaminan Sosial (BPJS), Undang-undang Nomor 36 Tahun 2009 tentang Kesehatan, Peraturan Menteri Kesehatan Nomor 40 Tahun 2012 tentang Pedoman Pelaksanaan Program Jamkesmas 2012, Peraturan Daerah Provinsi Jawa Tengah Nomor 10 Tahun 2009 tentang Penyelenggaraan Jamkesda Provinsi Jawa Tengah dan Peraturan Gubernur Jawa Tengah Nomor 73 Tahun 2010 tentang Petunjuk Pelaksanaan Penyelenggaraan Jaminan kesehatan daerah Provinsi Jawa Tengah. ${ }^{8}$

Sistem pengendalian untuk pelaksanaan Jamkesda meliputi kendali mutu dan kendali biaya. Kendali mutu menjadi domain pimpinan dalam memberikan pelayanan dengan menggunakan prosedur standart Operasional. Mekanisme klaim atau aduan

8 Peraturan Walikota Tegal Nomor 64 Tahun 2012 tentang Pedoman Pelaksanaan Jaminan Kesehatan Semesta Tahun 2013 masyarakat atas pelayanan kesehatan harus dimaksimalkan fungsinya ${ }^{9}$

Di dalam Rancangan UndangUndang Administrasi Pemerintahan Draft bulan Juli 2008 dalam Pasal 6 ayat (1) memberi batasan terhadap diskresi dengan menyebutkan bahwa Pejabat pemerintahan dan atau badan hukum lainnya yang menggunakan diskresi dalam mengambil keputusan wajib mempertimbangkan tujuan diskresi, peraturan perundang-undangan yang menjadi dasar diskresi dan asasasas umum pemerintahan yang baik. Selanjutnya ayat (2) dan ayat (3) menyebutkan bahwa penggunaan diskresi wajib dipertanggung jawabkan kepada pejabat atasannya dan masyarakat yang dirugikan akibat keputusan diskresi yang telah diambil serta dapat diuji melalui upaya administratif atau gugatan di Peradilan Tata Usaha Negara;

Ketentuan tersebut berarti bahwa Rancangan Undang-Undang Administrasi Pemerintahan bukan hanya akan memberi batasan penggunaan diskresi oleh Pemerintah, akan tetapi juga mengatur mengenai pertanggungjawaban Pemerintah terhadap penggunaan diskresi yang tidak hanya bersifat pasif dalam arti menunggu adanya gugatan dari masyarakat melalui Pengadilan Tata Usaha Negara akan tetapi juga bersifat aktif dengan adanya kewajiban dalam mempertanggungjawabkan penggunaan diskresi kepada Pejabat atasannya mengingat hal tersebut merupakan suatu kewajiban yang sifatnya melekat pada kewenangan yang menjadi dasar adanya diskresi itu sendiri dan di dalam penjelasannya disebutkan bahwa pertanggungjawaban kepada atasan dilaksanakan dalam bentuk tertulis dengan memberikan alasan-alasan pengambilan keputusan diskresi.

Tetapi yang disayangkan adalah meskipun Pasal 6 RUU Administrasi Pemerintahan telah mengatur tentang

9 Ibid. 
kewajiban melaporkan tindakan diskresi kepada atasan dalam bentuk tertulis dengan memberikan alasan-alasan pengambilan keputusan diskresi, namun apabila ketentuan tersebut tidak dilaksanakan tidak ada sanksinya sehingga hal tersebut dapat menyebabkan Badan/ Pejabat Administrasi Pemerintahan yang menerbitkan keputusan diskresi berdalih bahwa keputusan yang diambilnya bukan keputusan diskresi ataupun berdalih ia tidak tahu bahwa keputusan yang diambilnya adalah keputusan diskresi.

Walaupun demikian paling tidak dengan akan dijadikannya batasbatas penggunaan diskresi sebagai suatu norma yang mengikat, maka hal tersebut sudah cukup untuk menghindari dilaksanakannya penyalahgunaan wewenang (detournement de pouvoir) dan perbuatan sewenang-wenang (willekeur) oleh Badan/Pejabat Administrasi Pemerintahan, sebab tujuan utama dari normatifisasi adalah menciptakan dan menjadikan Hukum Administrasi Negara menunjang kepastian hukum yang memberi jaminan dan perlindungan hukum, baik bagi warga negara maupun administrasi negara.

Berdasarkan hal tersebut diatas, dapat disimpulkan bahwa penggunaan kewenangan diskresi oleh pemerintahan hanya dapat dilakukan dalam hal tertentu dimana peraturan perundang-undangan yang berlaku tidak mengaturnya atau karena peraturan yang ada bersifat tidak jelas dan hal tersebut dilakukan dalam keadaan darurat demi kepentingan umum yang telah ditetapkan dalam suatu peraturan perundang-undangan.

2. Kendala-Kendala Dalam Mengimplementasikan Kebijakan Diskresi Birokrasi Pemerintahan Daerah Sebagai Salah Satu Upaya Efektivitas Pelayanan Publik Di Kota Tegal

Persoalan-persoalan penting yang mendesak di dalam pemberian kewenangan diskresi oleh pejabat administrasi publik secara teoritis sekurang-kurangnya mengandung unsur-unsur sebagai berikut :

a. Persoalan-persoalan yang muncul harus menyangkut kepentingan umum, yaitu kepentingan bangsa dan negara, kepentingan masyarakat luas, kepentingan rakyat banyak bersama, serta kepentingan pembangunan.

b. Munculnya persoalan tersebut secara tiba-tiba, berada diluar rencana yang telah ditentukan.

c. Untuk menyelesaikan persoalan tersebut, peraturan perundangundangan belum mengaturnya atau hanya mengatur secara umum, sehingga administrasi negara mempunyai kebebasan untuk menyelesaikan atas inisiatif sendiri.

d. Prosedurnya tidak dapat diselesaikan menurut administrasi yang normal, atau jika diselesaikan menurut prosedur administrasi yang normal justru kurang berdaya guna dan berhasil guna.

e. Jika persoalan tersebut tidak diselesaikan dengan cepat, maka akan menimbulkan kerugian bagi kepentingan umum $^{10}$.

Namun dengan adanya freies ermessen ini berarti bahwa sebagian kekuasaan yang dipegang oleh badan pembentuk undang-undang dipindahkan ke dalam tangan pemerintah/administrasi negara, sebagai badan eksekutif. Jadi supremasi badan legislatif diganti oleh supremasi badan eksekutif karena administrasi negara melakukan penyelesaian masalah tanpa harus menunggu perubahan Undang-Undang dari bidang legislatif ${ }^{11}$. Hal tersebut karena pada prinsipnya Badan/Pejabat administrasi pemerintahan tidak boleh menolak untuk memberikan pelayanan kepada masyarakat dengan alasan

10 SF Marbun, Op.Cit. hlm.117.

11 A. Siti Soetami, 2000, Hukum Administrasi Negara, Badan Penerbit Universitas Diponegoro, Semarang, hlm.46. 
hukumnya tidak ada ataupun hukumnya ada tetapi tidak jelas, sepanjang hal tersebut masih menjadi kewenangannya.

Beberapa kebijakan diskresi birokrasi oleh Wali Kota Tegal yakni dalam kebijakan Jaminan Kesehatan Masyarakat Semesta dan Kebijakan Diskresi di bidang Pendidikan yang meliputi bea siswa penduduk miskin, bantuan untuk studi tour dan seragam serta Jaminan Kesehatan Masyarakat Semesta adalah produk kebijakan pemerintah Kota Tegal untuk menyelenggarakan pelayanan kesehatan bermutu dan berkeadilan dikhususkan atas pembiayaan masyarakat yang belum ditanggung oleh jaminan kesehatan lainnya terdapat beberapa kendala yang merupakan potential problem yang dapat terjadi selama proses pelaksanaan kebijakan diskresi baik kebijakan jaminan kesehatan maupun bidang pendidikan yakni sebagai berikut :

a. Biaya yang tidak mencukupi akibat demand yang berlebihan dari program diskresi birokrasi

b. Peserta kebijakan yang membengkak tidak sesuai dengan rencana yang telah ditetapkan misalnya peserta yang sebenarnya tidak dikategorikan miskin tetapi meminta diklasifikasikan sebagai keluarga miskin

c. Pelayanan administratif yang tidak lancar karena kebijakan diskresi birokrasi lebih merupakan program spontanitas dari pemerintah daerah.

\section{PENUTUP}

\section{KESIMPULAN}

a. Implementasi Kebijakan Diskresi birokrasi dalam pemerintahan daerah sebagai salah satu upaya efektivitas pelayanan publik di Kota Tegal diterbitkannya dalam keadaan mendesak yaitu suatu keadaan yang muncul secara tiba-tiba menyangkut kepentingan umum yang harus diselesaikan dengan cepat, dimana untuk menyelesaikan persoalan tersebut, peraturan perundang- undangan belum mengaturnya atau hanya mengatur secara umum dan keadaan tersebut tidak boleh tercipta karena kesalahan tindakan oleh Badan atau Pejabat Administrasi Pemerintahan yang melakukan diskresi. Pemerintah Kota Tegal mengeluarkan kebijakan diskresi yakni Jaminan Kesehatan.

b. Kendala-kendala di dalam diskresi birokrasi dalam pemerintahan daerah sebagai salah satu upaya efektivitas pelayanan publik di Kota Tegal adalah biaya yang tidak mencukupi akibat permintaan yang berlebihan dari program diskresi birokrasi, peserta kebijakan yang membengkak tidak sesuai dengan rencana yang telah ditetapkan misalnya peserta yang sebenarnya tidak dikategorikan miskin tetapi meminta diklasifikasikan sebagai keluarga miskin dan pelayanan administratif yang tidak lancar karena kebijakan diskresi birokrasi lebih merupakan program spontanitas dari pemerintah daerah

\section{SARAN}

Dalam mengantisasipasi penggunaan diskresi yang tidak sesuai dengan peraturan perundang-undangan dan asas-asas umum pemerintahan yang baik, maka Rancangan UndangUndang Administrasi Pemerintahan yang memuat aturan pokok mengenai diskresi harus segera diundangkan dan selanjutnya agar pengaturan mengenai diskresi yang lebih rinci diatur dalam Peraturan Pemerintah mengenai diskresi Pajabat Administrasi Pemerintahan sebagaimana diamanatkan oleh Pasal 6 ayat (4) Rancangan Undang-Undang Administrasi Pemerintahan dengan materi muatan antara lain tujuan dari Peraturan Pemerintah tentang diskresi pejabat administrasi pemerintahan, apa pengertian diskresi, "keadaan mendesak" dan "kepentingan umum", pejabat apa saja yang dapat melakukan/menerbitkan 
keputusan diskresi, dalam hal bagaimana diskresi dapat dilakukan, bagaimana pertanggungjawaban hukum pejabat yang menerbitkan keputusan diskresi, upaya administrasi yang dapat ditempuh oleh masyarakat dan lembaga mana yang berwenang menguji legalitas tindakan/keputusan diskresi.

\section{DAFTAR PUSTAKA}

\section{- Buku-buku}

A. Siti Soetami, Hukum Administrasi Negara, 2000, Badan Penerbit Universitas Diponegoro Semarang.

JCT Simorangkir dkk, 2008, Kamus Hukum, Sinar Grafika, Jakarta

Ronny Hanintijo Soemitro, 1990, Metode Penelitian Hukum dan Jurimetri, Ghalia Indonesia, Jakarta.

Samodra Wibawa, 2009, Administrasi Negara: Isu-Isu Kontemporer, Graha IImu, Yogyakarta.

SF Marbun, 2001, Menggali dan Menemukan Asas-asas Umum Pemerintahan yang Baik Di Indonesia, dalam SF Marbun dkk, Dimensi-Dimensi Pemikiran Hukum Administrasi Negara, UII Press, Yogyakarta.

S. Prajudi Atmosudirjo, 1994, Hukum Administrasi Negara, Ghalia Indonesia, Jakarta

Teguh Yuwono, Otonomi Daerah Berjalan di Tempat, Harian Umum Suara Merdeka, 28 Desember 2009

Warsito dan Teguh Yuwono, Otonomi Daerah: Capacity Building dan Penguatan Demokrasi Lokal, Puskodak-Undip, Semarang, 2003

\section{- Perundang-undangan}

Undang-undang Nomor 32 Tahun 2004 tentang Pemerintahan Daerah

Peraturan Walikota Tegal Nomor 64 Tahun 2012 tentang Pedoman Pelaksanaan Jaminan Kesehatan Semesta Tahun 2013 